\title{
Н.Н. Шпильная
}

\section{ДИАЛОГИЧЕСКИЙ ТЕКСТ КАК КОМПОНЕНТ НЕПРЕРЫВНОГО ДЕРИВАЦИОННО-ИНТЕРПРЕТАЦИОННОГО ПРОЦЕССА}

\begin{abstract}
Диалогический текст рассматривается в статье как компонент непрерывного деривационно-интерпретационного прочесса. Движущчим фактором деривационноинтерпретационного функционирования диалогического текста признается механизм нейтрализации, проявляющийся в процессах конвергенции и дивергенции его деривационных вариантов. Доказывается, что возникающий в результате нейтрализации диалогический текст соотносится с исходными дериваџионными вариантами по линии актуализации одной из модусных макропропозиций - вариантов структурной организации внутренней формы диалогического текста - согласования, контраста или примыкания.

Ключевые слова: диалогический текст, производный текст, непрерывный деривационно-интерпретационный процесс, нейтрализация, внутренняя форма диалогического текста.
\end{abstract}

Исходные положения. Цель статьи - продемонстрировать особенности проявления непрерывного деривационно-интерпретационного процесса в диалогической речи. В существующих работах, посвященных проблеме деривационного моделирования текста, последний обычно рассматривается как компонент непрерывного деривационно-мотивационного процесса [1]. Условием такого понимания деривации текста является осознание ее коммуникативно-гносеологической природы, ее обусловленности свойством мотивированности языкового знака, связанным с отражательным компонентом языковой способности носителя языка (см., например, [1-2]). В таком случае носитель языка интерпретируется как включатель / выключатель деривационной энергии языкового знака (см., например, [1-2]), т.е., по сути, как носитель языковой способности особого качества, особость которого обнаруживается в ее отражательной природе, что проявляется в объективном / субъективном отражении / неотражении тех или иных языковых элементов исходного языкового знака. Связь деривации с механизмом отражения / отображения объясняется ее (деривации) номинативной природой [3]. Следствием описанного подхода к представлению деривации текста является то, что ее конечный продукт - производный текст - предстает как монологический текст, производнономинативная единица. Рассмотрение производного текста как монологического текста возможно в том смысле, что он выполняет коммуникативногносеологическую функцию и соотносится с внеязыковой действительностью, пусть не непосредственно, а опосредованно - посредством внутриязыковой (внутритекстовой) референции, овеществления «кусочка» речеязыковой действительности.

Новизна сформулированной нами в начале статьи целевой установки обусловлена двумя обстоятельствами. Во-первых, предметом нашего 
рассмотрения является диалогическая речь. Во-вторых, диалогическая речь и ее продукт - диалогический текст - трактуются как проявление непрерывного деривационно-интерпретационного процесса - стержневой линии динамики языка. Как следствие диалогический текст рассматривается нами как производная единица языка / речи, а производный текст - как диалогический текст. Предлагаемый в статье подход к проблеме деривации текста соотносится с представлением о том, что язык, как социальная система, призван прежде всего обслуживать коммуникативную ситуацию диалогического типа, т.е. диалогическую ситуацию. Другим словами, язык устроен так, а не иначе еще и потому, что он позволяет каждому носителю языка одновременно обозначать себя и как адресата, и как адресанта, то есть как отвечающего, реагирующего на чужие речевые произведения - текстыобъекты - в метамодусном формате, соотносимым одновременно с я-сферой и mы-сферой. Об онтологической позиции говорящего как «отвечающего» говорит М.М. Бахтин. Ср.: «<..> всякий говорящий сам является в большей или меньшей степени отвечающим: ведь он не первый говорящий, нарушивший вечное молчание Вселенной» [4. С. 247]. Формальным показателем функциональной позиции отвечающий являются вторичные модусные предикаты подтверждения или отрицания, которые служат и средством авторизации, и средством адресации.

В центре внимания данной статьи - диалогический текст как компонент непрерывного деривационно-интерпретационного процесса.

Согласно развиваемой в статье концепции динамика языка обусловлена свойством интерпретируемости языкового знака, тенденциями языкового знака к интерпретируемости и к неинтерпретируемости, коррелирующими с процессами производства / воспроизводства языковых единиц и функциональной позицией субъекта речи - отвечающий [5]. Факт наличия в языковом знаке наряду с означаемым и означающим третьего компонента интерпретанты, которая обеспечивает развитие знака-объекта в знаке-цели, являющимся интерпретантой знака-объекта, позволяет говорить о связи интерпретации и производного языкового знака. Отношения интерпретанты и производных единиц языка описывается в лингвистической литературе схемой «знак за знак». Это означает, что производный знак - это знак, возникающий как интерпретанта знака-объекта и заменяющий последний в актах функционирования. О связи интерпретанты и производного слова говорит Е.С. Кубрякова, согласно которой интерпретантой последнего слова является «мотив обозначения, притом тот, который представлен материально в теле знака» [6. С. 248]. О связи интерпретанты и текста говорит Л.Г. Ким, исследующая проблему вариативно-интерпретационного функционирования текста в пространстве адресата [7]. Лингвистов интересует следовое проявление интерпретанты как составной части производного знака, вычленяемой в нем в силу дискретности ее формально-содержательной организации. Нас же интересует не следовое проявление интерпретанты, а процесс ее актуализации, который неразрывно связан с актами производства / воспроизводства языковых единиц.

Учитывая, что языковой знак всегда является интерпретантой, мы считаем, что деривация языковой единицы осуществляется как процесс актуализа- 
ции интерпретанты знака-объекта - интерпретационного «эмбриона» знакацели. При этом интерпретанта имитирует означаемое и означающее знакаобъекта и знака-цели в их единстве и опосредует их взаимодействие в создаваемом интерпретатором знаке. В этом смысле деривация и интерпретация образуют непрерывный деривационно-интерпретационный процесс как стержневую линию динамики языка, где деривация - это осуществление актов производства / воспроизводства языковых единиц, а интерпретация - это диалогическая реакция носителя языка (воздействие, осуществляемое знаком, по Ч. Моррису), обусловленная знаком-объектом и представленная либо модальностью согласия (подтверждения), либо модальностью несогласия (отрицания). Единство деривации и интерпретации обусловлено тем, что в процессе деривации языковой единицы как реализации интерпретанты предшествующей ей единицы также задается и вектор ее будущей интерпретанты - создаваемой единицы. Отсюда производная единица языка - это диалогический знак, т.е. знак, возникающий в результате синтеза интерпретационной активности личности и формальных суппозиций знака-основы.

Рассмотрение процесса создания диалогического текста как непрерывного деривационно-интерпретационного процесса предполагает признание универсального характера текстообразования, тождественность механизмов внутритекстовых и межтекстовых отношений, отсутствие «границ» между ними, а следовательно, и отсутствие текстовых границ. В таком случае создание диалогического текста объясняется действием двух взаимосвязанных процессов - конвергенции и дивергенции - как проявления механизма нейтрализации, обеспечивающего его (текста) деривационно-интерпретационное развитие.

Внутренняя форма диалогического текста как деривационноинтерпретационный феномен. Деривационная структура внутренней формы диалогического текста. В непрерывном деривационноинтерпретационном процессе проявляется установка носителя языка на учет формальной стороны языкового знака в актах его актуализации и экспликации. Следствием сказанного является возможность трактовать диалогический текст как производную единицу языка, возникающую в результате учета формальных суппозиций в актах его производства / воспроизводства. Создание диалогического текста описывается нами как процесс формальнокомбинаторного соподчинения текста-объекта и текста-цели, механизмом согласования которых является внутренняя форма диалогического текста, синтезирующая деривационно-диалогические свойства языка. При этом мы полагаем, что планом выражения производного - диалогического - текста является монологический текст, и это вполне закономерно, так как он обладает смыслоразличительной функцией, обнаруживаемой в способности дифференцировать фрагменты внеязыковой действительности. Как известно, к числу единиц плана выражения также относятся фонема и морфема. Разница между ними заключается только в том, что фонема, как единица плана выражения, служит для различения плана выражения морфемы, а морфема, в свою очередь, дифференцируют план выражения лексемы, тогда как монологический текст служит для различения внеязыковых фрагментов, поскольку 
«имеет точный референт - ситуацию - не представляющий собой результат условного языкового членения» [8. С. 355]. Представление монологического текста в качестве единицы плана выражения соотносится с принципом экземплярности, предполагающим единичную актуализацию языковых единиц. Статус диалогического текста в этом отношении подобен производному слову, которое также существует и на уровне абстрактного языкового функционирования (ср.: способы словообразования), и на уровне реального языкового функционирования (ср.: производное слово как готовая единица, как единица лексического уровня языковой системы).

Внутренняя форма диалогического текста как носитель потенциала его деривационно-интерпретационного функционирования имеет определенную структуру, отражающую принципы коммуникативного соединения и следования термов и представляющую собой соотношение текстообразовательной базы, текстообразовательного детерминанта и текстообразовательного форманта, выражаемое при помощи деривационного значения последнего.

Текстообразовательная база - это совокупность термов, способных детерминировать деривационное развитие текста. Текстообразовательный детерминант - это терм или совокупность термов, детерминирующих деривационное развитие текста; текстообразовательный формант текстообразующие термы, формирующие текст; деривационное значение значение пропозиционального форманта по отношению к пропозициональному детерминанту.

Далее мы исходим из того, что внутренняя форма диалогического текста представлена в виде глобальной модусной пропозиции, или модусной макропропозиции. Представляя внутреннюю форму диалогического текста в виде модусной макропропозиции, мы полагаем, что последняя отражает не столько денотативную ситуацию, сколько способ еe формальносодержательного воплощения в будущем диалогическом тексте. Мы считаем, что в составе модусной макропропозиции могут быть выделены модусный предикат и диктумные суппозиции. Базовые модусные предикаты - это предикаты согласен / не согласен. Модусный предикат, выражающий нейтральную диалогическую позицию носителя языка, мы квалифицируем как нулевой модусный предикат. Диктумный компонент модусной пропозиции представлен в виде диктумной суппозищии. Диктумная суппозиция - это информация, содержащаяся в тексте-объекте и в тексте-цели. В числе диктумных суппозиций могут быть выделены прагматические и коммуникаmивные. Прагматические суппозиции имеют своим референтом образ коммуникативного события - образ коммуникативного прошлого, образ коммуникативного будущего и образ коммуникативного настоящего. Выделенные виды прагматических термов соотносятся с описанными Ч. Пирсом типами отношений между интерпретантой и объектом: ремой как образом бытия позитивной качественной возможности, дицентом как образом бытия реального факта и аргументом (умозаключением) как образом бытия законности (или конвенциональности) [9]. Так, образ коммуникативного прошлого коррелирует с аргументом как образом бытия законности (так было), образ коммуникативного будущего - с ремой как образом бытия качественной воз- 
можности (к чему это может привести), а образ коммуникативного настоящего - с дицентом как образом бытия реального факта (так есть).

Коммуникативные суппозиции имеют своим референтом компоненты коммуникативной ситуации; к ним мы относим образ автора, образ адресата, образ кода, образ контакта, образ сообщения, образ контекста. Выделенные коммуникативные термы соотносятся с компонентами коммуникативного акта, выделенными Р.О. Якобсоном в [10].

Варианты структурной организации внутренней формы диалогического текста. Согласно развиваемой в работе концепции внутренняя форма диалогического текста, функционально детерминируемая ситуацией диалога, соотносится прежде всего с фатической функцией языка. Как следствие внутренняя форма диалогического текста обладает фатическим ракурсом. Фатический ракурс внутренней формы проявляется в способе формального согласования двух речевых произведений как проекции будущего диалогического текста. Фатически-ориентированная внутренняя форма характеризуется следующей структурной организацией: коммуникативный терм образ адpecama + модусный предикат. Как видим, текстообразовательный детерминант - коммуникативный терм образ адресата - это суппозиция со стороны субъекта речи как адресата, а текстообразовательный формант - модусный предикат - это суппозиция со стороны субъекта речи как адресанта.

Подчеркнем принципиальный момент. В качестве адресата сообщения могут выступать как третьи лица, которые упоминаются в сообщении, так и те, кому адресовано сообщение. Это объясняется функциональной позицией носителя языка, выступающего в актах коммуникации в статусе отвечающего. Иными словами, носитель языка своим сообщением подтверждает или не подтверждает то или иное высказывание. В зависимости от этого, т.е. от того, чье высказывание он подтверждает или не подтверждает, мы и квалифицируем статус адресата сообщения, понимая, конечно, что адресатами выступают и носители языка, прочитавшие и / или оставившие свои комментарии к нему. Некоторое противоречие объяснимо тем, что исходный текст может быть подан как обезличенный при наличии реального автора. Таковыми зачастую являются тексты новостных статей, размещенных в сети Интернет; их обезличенность объясняется введением в текст диалогических позиций третьих лиц - губернатора, мэра, министра, артиста и пр., которые (позиции) и провоцируют ответную реакцию носителя языка, прочитавшего это сообщение.

Наши наблюдения над языковым материалом (интернет-комментариями к новостным статьям, проанализировано 834 комментария) позволили выделить три типа фатических модусных макропропозиций, на основе которых осуществляется деривационное развитие диалогического текста.

1-й тип - макропропозиция-примыкание - наблюдается в случае, если производный (диалогический) текст обладает нулевым модусным предикатом, т.е. он создается по модели коммуникативный терм образ адресата + нулевой модусный предикат.

2-й тип - макропропозиция-контраст - имеет место в случае, если производный (диалогический) текст создается по модели коммуникативный терм образ адресата + модусный предикат не согласен. 
3-й тип - макропропозиция-согласование - имеет место в том случае, когда диалогический / производный текст создается по модели коммуникативный терм образ адресата + модусный предикат согласен.

Выявленные варианты структурной организации диалогического текста представляют собой деривационные варианты диалогического текста. См. подробнее в [11].

Нейтрализация деривационных вариантов диалогического текста как механизм его деривационно-интерпретационного развития. Охарактеризовав возможные варианты деривационного развития диалогического текста, остановимся подробнее на описании механизма их нейтрализации как движущего фактора деривационно-интерпретационного функционирования языковых единиц.

Как известно, термин «нейтрализация» используется в фонологии для обозначения явления совпадения различных фонем в одном аллофоне. При этом показателем их нейтрализации является невозможность выполнения фонемами сигнификативных (смыслоразличительных) функций. По отношению к единицам двусторонним принято различать нейтрализацию единиц плана выражения, совпадающих в одной форме, но различающихся по значению, и плана содержания, соотносимых с различными формами, но контекстуально совпадающими. Нейтрализация структурных вариантов языковой единицы сопровождается сначала их конвергенцией, а далее (возможно) дивергенцией. См. об этом подробнее в [12]. Проецируя основные положения теории нейтрализации на проблему деривации диалогического текста, отметим, что процесс его образования (функционирования) обеспечивается механизмом нейтрализации, приводящим, с одной стороны, к совпадению двух и более деривационных вариантов диалогического текста (процесс конвергенции) в одном варианте и утрате ими информативных (смыслоразличительных) функцией, а с другой стороны, к появлению новых деривационных вариантов (процесс дивергенции), приобретающих тот или иной информативный ракурс.

Конвергенция деривационных вариантов диалогического текста. Под конвергенцией деривационных вариантов диалогического текста мы понимаем процесс совпадения двух и более его вариантов в каком-либо одном деривационном варианте, структурно совпадающем или не совпадающем с исходными вариантами. В основе конвергенции деривационных вариантов диалогического текста лежит механизм выравнивания по аналогии. Иными словами, нейтрализация деривационных вариантов диалогического текста сопровождается их выравниванием относительно коммуникативного терма образ адресата. При этом возникающий в результате нейтрализации диалогический текст соотносится с исходными деривационными вариантами по линии соотношения с модусными предикатами согласен, не согласен или нулевым модусным предикатом.

Для иллюстрации процесса конвергенции деривационных вариантов диалогического текста обратимся к анализу интернет-комментариев к новостной статье «Переходы в метро: гопники вместо цветов» (http://news. ngs. ru/ more/1253828/). Содержание данной статьи может быть представлено следующим образом: Губернатор Василий Юрченко распорядился очистить все 
вестибюли новосибирского метрополитена от торговых киосков в цеелях обеспечения жителей города от терроризма и гопников.

\section{ЕленаS}

10 июля 2013 08: 46

Я против!!! Это очень не удобно, бежать в ТЦ который работает с 10 утра за необходимыми вещчами!!! а вот пустые переходы куда строшнее!!

Деривационно-интерпретационную структуру внутренней формы данного текста можно представить следующим образом:

\begin{tabular}{c|c}
\hline $\begin{array}{c}\text { Текстообразовательный } \\
\text { детерминант }\end{array}$ & $\begin{array}{c}\text { Текстообразовательный } \\
\text { формант }\end{array}$ \\
\cline { 1 - 2 } образ адресата & модусный предикат не согласен \\
\hline нулевой модусный предикат & \\
\hline
\end{tabular}

Создание данного диалогического текста обусловлено актуализацией фатически-ориентированной макропрозиции-контраста. Фатический ракурс внутренней формы задается макропропозицией-контраста, в составе которой выделяются модусный предикат не согласен (я против) и текстообразовательный терм образ адресата. Автор текста не согласен с диалогической позицией губернатора Юрченко, который и выступает в качестве адресата сообщения.

Мила_Я

10 июля 2013 09: 28

Интересно, что будет делать Юрченко, когда у нас в метро начнут сумки отбирать или того хуже...

время покажет...

но мне эта идея, ох как не нравится...

Деривационно-интерпретационную структуру внутренней формы данного текста можно представить следующим образом:

\begin{tabular}{c|c}
\hline $\begin{array}{c}\text { Tекстообразовательный } \\
\text { детерминант }\end{array}$ & $\begin{array}{c}\text { Текстообразовательный } \\
\text { формант }\end{array}$ \\
\cline { 1 - 1 } образ адресата & \multirow{2}{*}{ модусный предикат не согласен } \\
\hline нулевой модусный предикат & \\
\hline
\end{tabular}

Схема показывает, что фатический ракурс внутренней формы диалогического текста представлен макропропозицией-контраста, о чем свидетельствует наличие в ее структуре модусного предиката не согласен (мне эта идея не нравится) и коммуникативного терма образ адресата (господин Юрченко инициатор данной идеи).

Наталья ${ }^{\text {гость }}$

10 июля 2013 09: 27

Городские власти, опомнитесь! Видеокамеры как защита от хулиганов? У нас полищия игнорирует просьбы о помощи, когда возникает прямая опасность здоровью человека, типичная хохма «пока трупа нет, не выезжаем». 
Переход с Красного проспекта на Сибирскую заставлен бутылками и забросан окурками, постоянно! Хотя там 2 видеокамеры, все равно умудряются мочиться на стены, пить пиво. Вы думаете российские полищейские бдительно всматриваются в мониторы? Откуда тогда массовые драки и грязь на платформах, полупьяные и неадекватные? Пристальное внимание заслуживают только гастарбайтеры рабочие, и никак не качки и агрессивная шиана.

Убирая киоски, где можно приобрести элементарные средства гигиены, газеты и кусок хлеба вы уничтожсаете мальй бизнес, превращаете переходы в бесконтрольные пустыри, фактически подвергая еще большей опасности обычных людей.

\section{Это просто бессовестно!}

Деривационно-интерпретационную структуру внутренней формы данного текста можно представить следующим образом:

\begin{tabular}{c|c}
\hline $\begin{array}{c}\text { Текстообразовательный } \\
\text { детерминант }\end{array}$ & $\begin{array}{c}\text { Текстообразовательный } \\
\text { формант }\end{array}$ \\
\cline { 1 - 1 } образ адресата & модусный предикат не согласен \\
\hline нулевой модусный предикат & модед \\
\hline
\end{tabular}

Как видим, фатический ракурс внутренней формы данного диалогического текста также задается макропропозицией-контраста, в составе которой выделяются модусный предикат несогласия не согласен и коммуникативный терм образ адресата (городские власти). Очевидно, что автор текста не согласен с действиями властей, которые планируют закрыть торговые киоски в метро (это просто бессовестно).

\section{Пиркс ${ }^{\text {гость }}$}

10 июля 2013 09: 41

Плохое, нелогичное, необдуманное решение. На свидании как идешь, так иветы всегда в метро покупаешь... Выглядит как продолжение эпопеи с повышением налогов для ИП = Лоббирование интересов крупного бизнеса... А ТЦ сейчас как всегда абсурдно поступят - завысят ар. Плату для ИП... Руководство города думает, что у нас кримогенная ситуация лучшая в РФ или даже в мире???

Деривационно-интерпретационную структуру внутренней формы данного текста можно представить следующим образом:

\begin{tabular}{|c|c|}
\hline $\begin{array}{c}\text { Tекстообразовательный } \\
\text { детерминант }\end{array}$ & $\begin{array}{c}\text { Tекстообразовательный } \\
\text { формант }\end{array}$ \\
\hline образ адресата & \multirow{2}{*}{$\begin{array}{c}\text { модусный предикат } \\
\text { не согласен }\end{array}$} \\
\hline нулевой модусный предикат & \\
\hline
\end{tabular}

Из схем видно, что фатический ракурс внутренней формы диалогического текста задается модусной макропропозицией-контраста. Так, в ее структуре выделяются модусный предикат несогласия не согласен и коммуникативный терм образ адресата (Плохое, нелогичное, необдуманное решение). 
дауж гость

10 июля 2013 10:01

Сначала под благим предлогом убираем киоски, потом под благим предлогом взвинчиваем тарифы. Уберут киоски - уменьшится количество денег от аренды поступающее в метрополитен, уменьиится количество денег поднимут тарифы на проезд. В прошльй раз когда поднимали тарифы обещзали что поезда начнут ходить чаще, и ничего подобного - как ходили, так и ходят с прежними интервалами. Так что, еще один сравнительно честный способ отнять деньги у населения.

Деривационно-интерпретационную структуру внутренней формы данного текста можно представить следующим образом:

\begin{tabular}{|c|c|}
\hline $\begin{array}{c}\text { Текстообразовательный } \\
\text { детерминант }\end{array}$ & $\begin{array}{c}\text { Текстообразовательный } \\
\text { формант }\end{array}$ \\
\hline образ адресата & \multirow[t]{2}{*}{$\begin{array}{c}\text { модусный предикат } \\
\text { не согласен }\end{array}$} \\
\hline нулевой модусный предикат & \\
\hline
\end{tabular}

Схема показывает, что фатический ракурс внутренней формы анализируемого диалогического текста образован макропропозицией-контраста, маркером которой является модусный предикат не согласен, косвенно выражающий диалогическую позицию несогласия носителя языка с действиями губернатора; ср.: еще один сравнительно честный способ отнять деньги у населения.

Grey ${ }^{\text {гость }}$

10 июля 2013 10:06

Ещее один бред наших управителей.

Сам по молодости держал киоск с дисками в переходе метро.

Все продавиы друг-друга знают и следят за порядком в переходе не хуже органов.

Именно мы, а не охрана, гоняли оттуда попрошаек и "смердил"-бомжей заходивших погреться.

А это-лоббирование интересов владельцев ТЦ с их эпической арендой.

Это-устранение их конкурентов торгующих дешевле -малого бизнеса.

Это - неудобство для граждан, которые вынуждены идти куда-то за покупками а не совершать их по дороге.

Деривационно-интерпретационную структуру внутренней формы данного текста можно представить следующим образом:

\begin{tabular}{|c|c|}
\hline $\begin{array}{c}\text { Tекстообразовательный } \\
\text { детерминант }\end{array}$ & Текстообразовательный формант \\
\hline образ адресата & \multirow{2}{*}{ модусный предикат не согласен } \\
\hline нулевой модусный предикат & \\
\hline
\end{tabular}

Анализ данного диалогического текста показывает, что фатический ракурс его внутренней формы образован макропропозицией-контраста, структурообразующими компонентами которой являются модусный предикат не согласен и коммуникативный терм образ адресата. Ср.: ещзе один бред наших 
управителей. А информативный ракурс образован адресанто-ориентированной макропропозицией. Несогласие с действием властей выражается посредством актуализации прагматического терма - образа коммуникативного прошлого. Ср.: Сам по молодости держал киоск с дисками в переходе метро. Все продавиь друг-друга знают и следят за порядком в переходе не хуже органов. Именно мы, а не охрана, гоняли оттуда попрошаек и "смердил"-бомжей заходивших погреться.

\section{$\ddot{\mathbf{E}} \mathbf{k}$}

\section{0 июля 2013 10:25}

Какие пессимистичные сегодня коментаторы))) Зато места больше станет, а толкотни меньше. Шоколадку купить и в ларьке можно, круглосуточных киосков по линии метро пока хватает как и магазинов с колготками, носками, батарейками и иветами. А точки с ворованными телефонами и пиратскими дисками вообще работают благодаря серьезному недосмотру полиции, и привлекают в метрополитен все тех же гопников.

Деривационно-интерпретационную структуру внутренней формы данного текста можно представить следующим образом:

\begin{tabular}{|c|c|}
\hline $\begin{array}{c}\text { Tекстообразовательный } \\
\text { детерминант }\end{array}$ & $\begin{array}{c}\text { Tекстообразовательный } \\
\text { формант }\end{array}$ \\
\hline образ адресата & \multirow{2}{*}{$\begin{array}{c}\text { модусный предикат } \\
\text { не согласен }\end{array}$} \\
\hline нулевой модусный предикат & \\
\hline
\end{tabular}

Схема показывает, что фатический ракурс данного диалогического текста представлен макропропозицией-контраста, в которой нейтрализуются предыдущие деривационные варианты текста-основы. Нейтрализация последних обусловлена их выравниванием относительно коммуникативного терма образ адресата. Ср.: Какие пессимистичные сегодня коментаторы)))

Таким образом, наблюдается процесс конвергенции деривационных вариантов диалогического текста, предполагающий их нейтрализацию, т.е. совпадение в одном деривационном варианте.

Дивергенция диалогического текста. Под дивергенцией диалогического текста мы понимаем процесс появления новых деривационных вариантов текста из текста-основы (деривационный вариант, возникающий в результате нейтрализации) посредством формального согласования модусных предикатов как структурообразующих компонентов их внутренних форм. Между текстом-основой и его деривационными вариантами возможны отношения согласования, контраста или примыкания.

Рассмотрим примеры. Для удобства описания присвоим каждому деривационному варианту порядковый номер.

\section{ДВТ-1}

Евгения ${ }^{\text {гость }}$

\section{0 июля 2013 09:42}

Абсолютно согласна с большинство! Вижу только минусы в отсутствии киосков в переходах: 
1) по-быстренькому ничего не купишь, ни шоколадку, ни колготки;

2) идти по пустому тоннелю очень страшно и не приятно, особенно в вечерние часы!

3) люди теряют работу, деньги!

Боже, помоги нашим властям опомниться, свернуть с этого пути!

Губернатор Юрченко! Я вас до последних событий очень уважала, но это уже чересчур!

ДВТ-2

Виталька Каменский

10 июля 2013 13:58

Евгения, большинство - это хозяева киосков и продавцьь :)

ДВТ-3

lexandr

\section{0 июля 2013 15:53}

Евгения, пустьнный переход бывает только по вечерам, когда киоски уже не работают. В чем конкретно для вас будет разница?

ДВТ-1 представляет собой диалогический текст, возникший в результате конвергенции, т.е. совпадения нескольких деривационных вариантов диалогического текста, их выравнивания относительно коммуникативного терма образ адресата. Формальным показателем нейтрализации деривационных вариантов диалогического текста является высказывание Абсолютно согласна с большинством.

Деривационно-интерпретационную структуру ДВТ-1 можно представить следующим образом:

\begin{tabular}{c|c}
\hline $\begin{array}{c}\text { Текстообразовательный } \\
\text { детерминант }\end{array}$ & $\begin{array}{c}\text { Текстообразовательный } \\
\text { формант }\end{array}$ \\
\hline образ адресата & модусный предикат согласен \\
\hline модусный предикат не согласен & \\
\hline
\end{tabular}

Как видим, ДВТ-1 создается в результате актуализации макропропозиции-согласования, о чем свидетельствует наличие в ее структуре модусного предиката согласен и коммуникативного терма образ адресата.

ДВТ-2 - это диалогический текст, возникший в результате дивергенции ДВТ-1.

Деривационно-интерпретационная структура внутренней формы диалогического текста выглядит следующим образом:

\begin{tabular}{|c|c|}
\hline $\begin{array}{c}\text { Tекстообразовательный } \\
\text { детерминант }\end{array}$ & $\begin{array}{c}\text { Текстообразовательный } \\
\text { формант } \\
\end{array}$ \\
\hline образ адресата & \multirow[t]{2}{*}{ нулевой модусный предикат } \\
\hline нулевой модусный предикат & \\
\hline
\end{tabular}

Как видим, ДВТ-2 и ДВТ-1 связаны отношениями примыкания, так как пропозициональный формант содержит нулевой модусный предикат. Автор текста выражает нейтральную диалогическую позицию, он объясняет адреса- 
ту - Евгении, почему большинство комментариев не одобряет позицию властей.

ДВТ-3, подобно ДВТ-2, - это диалогический текст, возникший в результате формального согласования с ДВТ1 по линии примыкания, так как пропозициональный формант образован нулевым модусным предикатом.

Деривационно-интерпретационную структуру внутренней формы диалогического текста можно представить следующим образом:

\begin{tabular}{c|c}
\hline $\begin{array}{c}\text { Текстообразовательный } \\
\text { детерминант }\end{array}$ & $\begin{array}{c}\text { Текстообразовательный } \\
\text { формант }\end{array}$ \\
\cline { 1 - 1 } образ адресата & нулевой модусный предикат \\
\hline нулевой модусный предикат & \\
\hline
\end{tabular}

Подводя итог, отметим, что возникающие в результате дивергенции диалогического текста деривационные варианты связаны различными формальными отношениями с исходным для них текстом.

Заключение. Рассмотрение деривации текста - диалогического текста сквозь призму непрерывного деривационно-интерпретационного процесса позволяет показать имманентную связь процессов производства / воспроизводства языковых единиц с условиями их употребления (функционирования). Анализ суппозиционной - интерпретационной - основы деривационного процесса говорит о том, что она играет активную роль в этом процессе, поскольку данный процесс, с одной стороны, управляется представлением о будущем образе создаваемой языковой единицы, а с другой - формальными свойствами мотивируемой единицы. Осознание диалогического текста компонентом непрерывного деривационно-интерпретационного процесса становится возможным в силу признания двух тенденций языкового знака - тенденции к интерпретируемости и тенденции к неинтерпретируемости, соотносимых с процессами производства / воспроизводства языковых единиц и предполагающих проявление интерпретационной - диалогической - активности носителя языка.

Движущим фактором деривационно-интерпретационного функционирования диалогического текста является механизм нейтрализации, проявляющийся в процессах конвергенции и дивергенции его деривационных вариантов. При этом последние отражают тот или иной способ структурной организации внутренней формы диалогического текста как носителя потенциала его деривационно-интерпретационного развития.

Возникающий в результате нейтрализации диалогический текст соотносится с исходными деривационными вариантами по линии актуализации одной из модусных макропропозиций - согласования, контраста или примыкания.

Безусловно, в теории диалога накоплено немало наблюдений относительно модусно-диктумного согласования и рассогласования как детерминаций текстообразования. См., например, [13]. Однако данные текстопорождающие детерминанты рассматриваются как проявление коммуникативного намерения носителя языка, соотносимого с передачей нового сообщения; в центре внимания исследователей - тема-рематическая динамика диалогического 
текста в ситуации диалога. При этом очевидно, что функциональные основания языковой формы соотносятся с коммуникативной функцией языка в ее телеологическом варианте (язык - цель), из чего следует, что диктальные и модусные установки носителя языка отражают новизну содержания как внешнюю детерминанту текстообразования.

В данном исследовании реализованы другие методологические презумпции. Нас интересуют внутренние детерминанты текстообразования. Мы полагаем, что модусные макропропозиции, как формальные предструктуры диалогического текста, соотносимые с коммуникативной функцией языка в ее фатической ориентации (язык - объект), отражают не новизну высказывания, а новизну факта высказывания, соотносимую с диалогической позицией носителя языка, эквивалентом которой является вторичный модусный предикат. Отметим, что если новизна содержания коррелирует с вопросом Что сказать?, то новизна факта высказывания - с вопросом Что сказано и что я могу по этому поводу сказать (зачем мне вступать в коммуникацию)? В таком случае новизна содержания вторична по отношению к новизне факта высказывания и определяется суппозицией «сказано». Это и позволяет трактовать диалогический текст как производный текст и наоборот - производный текст как диалогический текст, существование которого объясняется непрерывным деривационно-интерпретационным процессом как стержневой линией динамики языка.

\section{Лuтература}

1. Голев Н.Д. Динамический аспект лексической мотивации. Томск: Изд-во Том. ун-та, 1989. $252 \mathrm{c}$.

2. Мельник Н.В. Деривационное функционирование русского текста: лингвоцентрический и персоноцентрический аспекты: дис. ... д-ра филол. наук. Кемерово, 2011. 403 с.

3. Никитевич B.M. Основы номинативной деривации. Минск: Высш. шк., 1985. 158 с.

4. Бахтин М.М. Собрание сочинений. Т. 5: Работы 1940-1960-х гг. М.: Рус. сл.; Языки славянской культуры, 1997.735 с.

5. Шпильная Н.Н. Принципы деривационного моделирования текстообразования // Вопросы когнитивной лингвистики. 2014. № 4. С. 73-84.

6. Кубрякова E.C. Язык и знание: На пути получения знаний о языке: части речи с когнитивной точки зрения. Роль языка в познании мира. М.: Языки славянской культуры, 2004. $560 \mathrm{c}$.

7. Ким Л.Г. Вариативно-интерпретационное функционирование текста. Томск: Изд-во Том. гос. пед. ун-та, 2009. $312 \mathrm{c.}$

8. Гак В.Г. Высказывание и ситуация // Проблемы структурной лингвистики. 1972. М.: Наука, 1973. С. 349-372.

9. Thellefsen T. Firstness and Thirdness Displacement: The Epistemology within Peirce's Three Sign Thrichotomies // C.S. Peirce. Digital Encyclopedia, 2000. URL: http:// www.tr 3C.com. br/ pierce/home.html

10. Якобсон Р.О. Лингвистика и поэтика // Структурализм: «за» и «против». М.: Прогресс, 1975. C. $193-230$.

11. Шиильная Н.Н. Внутренняя форма текста как деривационный феномен // Вестн. Том. гос. ун-та. 2013. № 373. С. 44-50.

12. Лингвистический энциклопедический словарь / гл. ред. В.Н. Ярцева. 2-е изд., доп. М.: Большая рос. энцикл., 2002.709 с.

13. Балаян А.P. Основные коммуникативные характеристики диалога: автореф. дис. ... канд. филол. наук. М., 1971. 19 с. 


\section{DIALOGICAL TEXT AS A COMPONENT OF THE DERIVATIVE INTERPRETATIVE PROCESS.}

Tomsk State University Journal of Philology, 2015, 4(36), pp. 56-70. DOI 10.17223/19986645/36/5

Shpilnaya Nadezhda N., Altai State Pedagogical University (Barnaul, Russian Federation).

E-mail:venata85@mail.ru

Keywords: dialogical text, derivative text, continuous derivative interpretative process, neutralization, internal form of dialogical text.

The article aims at showing special features of the continuous derivative interpretative process in a dialogue. Formal (static) models describing dialogical texts that dominated in the 1940s-1980s are declarative, so the language may be represented statically in the cognition theory only. These models have no explanatory power and cannot claim for an adequate cognition of the object of study ontologically.

The academic novelty of the aim is justified by two reasons. Firstly, the subject to consider is a dialogue. Secondly, the dialogue and its product, a dialogical text, are justified by manifestation of a continuous derivative interpretative process as the core of language dynamics. Consequently, a dialogical text is considered as a derivative language/speech unit, and a derivative text as a dialogical text.

The article focuses on a dialogical text as a component of the continuous derivative interpretative process According to the conception developed in the article, language dynamics is stipulated by the property of language sign interpretability, tendencies of a language sign to be interpreted and not to be interpreted related to language unit production/reproduction and the functional position of a speech subject taking part in communication acts in the status of a responder.

Neutralization mechanism appearing in convergence and divergence of its derivative options is recognized as a critical engine of derivative interpretative dialogical text functioning. The process of two or more options in a derivative variant structurally matching or not matching the original version is understood as convergence of a dialogical text derivative options. The mechanism of aligning by analogy accounts for convergence of derivative options of a dialogical text. In other words, neutralization of the derivative option of a dialogical text is accompanied by their aligning in relation to the communicative term addressee image. The process of appearance of new derivative options of the text from the basic text (derivative version appearing as a result of neutralization) with the help of a formal accordance of modus predicates as structuring components of their internal forms is understood as a dialogical text divergence.

Dialogical text derivative versions reflect the means of the internal form structural organization of a dialogical text as a potential carrier of its derivative interpretative development. It is proved that a dialogical text appearing as a result of neutralization relates to original derivative versions in terms of actualization of one of modus macropropositions, versions of the structural organization of a dialogical text internal form: concord, contrast or adjunction.

\section{References}

1. Golev, N.D. (1989) Dinamicheskiy aspekt leksicheskoy motivatsii [The dynamic aspect of lexical motivation]. Tomsk: Tomsk State University.

2. Mel'nik, N.V. (2011) Derivatsionnoe funktsionirovanie russkogo teksta: lingvotsentricheskiy $i$ personotsentricheskiy aspekty [Derivational functioning of the Russian text: linguo-centric and personcentric aspects]. Philology Dr. Diss. Kemerovo.

3. Nikitevich, V.M. (1985) Osnovy nominativnoy derivatsii [Basics of nominative derivation]. Minsk: Vysshaya shkola.

4. Bakhtin, M.M. (1997) Sobranie sochineniy [Works]. V. 5. Moscow: Russkie slovari; Yazyki slavyanskoy kul'tury.

5. Shpil'naya, N.N. (2014) Printsipy derivatsionnogo modelirovaniya tekstoobrazovaniya [Principles of derivational modelling of text creation]. Voprosy kognitivnoy lingvistiki. 4. pp. 73-84.

6. Kubryakova, E.S. (2004) Yazyk i znanie. Na puti polucheniya znaniy o yazyke: chasti rechi s kognitivnoy tochki zreniya. Rol' yazyka v poznanii mira [Language and Knowledge. On the way of acquiring knowledge of the language: the parts of speech from the cognitive point of view. The role of language in the cognition of the world]. Moscow: Yazyki slavyanskoy kul'tury.

7. Kim, L.G. (2009) Variativno-interpretatsionnoe funktsionirovanie teksta [Variable and interpretive text functioning]. Tomsk: Tomsk State University. 
8. Gak, V.G. (1973) Vyskazyvanie i situatsiya [Utterance and the situation]. In: Shaumyan, S.K. (ed.) Problemy strukturnoy lingvistiki. 1972 [Problems of structural linguistics. 1972]. Moscow: Nauka.

9. Thellefsen, T. (2000) Firstness and Thirdness Displacement: The Epistemology within Peirce's Three Sign Thrichotomies. In: Peirce, C.S. Digital Encyclopedia [Online]. Available from: http://www.tr3C.com.br/pierce/home.html.

10. Jacobson, R.O. (1975) Lingvistika i poetika [Linguistics and Poetics]. In: Strukturalizm: "za”" $i$ "protiv" [Structuralism: "pro" et "contra"]. Moscow: Progress.

11. Shpil'naya, N.N. (2013) Internal form of the text as a derivational phenomenon. Vestnik Tomskogo gosudarstvennogo universiteta - Tomsk State University Journal. 373. pp. 44-50. (In Russian).

12. Yartseva, V.N. (ed.) (2002) Lingvisticheskiy entsiklopedicheskiy slovar' [Linguistic encyclopedic dictionary]. 2nd ed. Moscow: Bol'shaya rossiyskaya entsiklopediya.

13. Balayan, A.R. (1971) Osnovnye kommunikativnye kharakteristiki dialoga [Basic communication characteristics of the dialogue]. Abstract of Philology Cand. Diss. Moscow. 